FILOZOFIA

Roč. 75,2020 , с̌. 6

DOI: https://doi.org/10.31577/filozofia.2020.75.6.4

\title{
PROČ CHÁPAT POPPERŮV KRITICKÝ DUALISMUS DECISIONISTICKY
}

JAN BURÁŇ, Katedra filozofie, Filozofická fakulta, Univerzita Palackého v Olomouci, Olomouc, $\check{C} R$

BURÁŇ, J.: Why Popper's Critical Dualism Should Be Understood Decisionistically

FILOZOFIA, 75, 2020, No 6, pp. $474-489$

There is not much in The Open Society to suggest that Karl Popper was a moral objectivist. Yet, that is exactly what he himself claimed later in life. Was the widespread "decisionistic" reading of The Open Society just a grand misunderstanding, or did Popper change his metaethical views without acknowledging it? I give reasons as to why we should hold the latter to be true. I also argue that even were the former the case, decisionism would still be more compatible with the open society ideal.

Keywords: Critical dualism - Is-ought - Karl Popper - Open society - Moral objectivism - Moral relativism

V původním textu jeho hlavního politického díla mnoho nenaznačuje, že by Karl Popper byl morálním objektivistou. A přece právě to si myslí mj. Jeremy Shearmur, který léta pracoval jako Popperův asistent a svou akademickou kariéru zasvětil komentování a rozvíjení jeho politické filosofie. Co víc, Popper sám se později k objektivismu hlásil. Bylo široce rozšiřřené decisionistické čtení Otevřené společnosti jen velkým nedorozuměním, nebo Popper změnil své metaetické postoje, aniž se $\mathrm{k}$ tomu přiznal? Přikláním se ke druhé variantě. Předkládám také důvody svého přesvědčení, že i pokud by platila první varianta, decisionismus lépe odpovídá ideálu otevřené společnosti. $^{1}$

Dosavadní literaturu týkající se tématu lze rozdělit do čtyř kategorií: a) ti, kteří interpretují Poppera decisionisticky a v tomto ohledu s ním souhlasí: např. Boyle 1974 či Mettenheim 1999; b) ti, kteří interpretují Poppera decisionisticky a v tomto ohledu s ním polemizují: O’Hear 1980, Hayes 2009; c) ti, kteří interpretují Poppera decisionisticky a k plauzibilitě jeho postoje se nevyjadřují: Keuth 2005 (a snad také Miller 1999 a Stelzer 2009); d) ti, kteří interpretují Poppera objektivisticky (a v tomto ohledu s ním souhlasí): Shearmur 1996, Pralongová 1999, Shearmur 2009, Naraniecki 2009.

${ }^{1}$ Za téma vděčím anonymnímu recenzentu mého předchozího článku. Viz Buráň 2019, pozn. 30. 
Nakolik je mi známo, v česko-slovenském prostředí se tématu doposud nejvíce přiblížil Cehelník 2009, který nicméně v otázce decisionismus vs. objektivismus vyznívá paradoxně (nese rysy (a) i (d)). Můj text by bylo možné volně vřadit do kategorie (a), od ostatních zástupců této skupiny se ale liší jednak co do aktivní polemiky s představiteli jiných kategorií, jednak v názoru, že Popper ve druhé polovině svého dlouhého života metaetický postoj změnil a stal se objektivistou.

Článek má dva oddíly. V prvním představuji decisionistickou a objektivistickou interpretaci kritického dualismu a argumentuji, že navzdory Popperově pozdějšímu přihlášení k objektivismu odpovídá Otevřené společnosti lépe interpretace decisionistická. Ve druhém oddílu se přesouvám od interpretace $\mathrm{k}$ filosofii a ve vztahu k jmenovaným metaetickým postojům podrobněji rozebírám klíčový problém relativismu a možností racionální kritiky.

\section{Proč, Popperovi navzdory, interpretovat Otevřenou společnost decisionisticky}

Kritický dualismus fakti̊ a norem je podle Poppera jednou z nutných podmínek otevřené společnosti. Umožňuje rozlišovat na jedné straně přirodní zákony (např. zákony fyziky), které jsou dané, a lze je tedy pouze objevovat a popisovat, a na straně druhé normativni zákony, které mohou být tvořeny a měněny člověkem, a „... je to tedy člověk, kdo za ně mravně odpovídá: ne snad za normy, které nachází ve společnosti, když je vůbec začíná reflektovat, ale za normy, které je ochoten tolerovat, přestože si je vědom, že může pracovat na jejich změně“ (Popper 2011, zvl. 67 - 93; 71).

Kritický dualista tak odmítá logiku Rousseauova člověk se rodí svobodný, ale všude je v okovech. Uvědomuje si totiž, že „rozhodnutí postavit se proti otroctví nezávisí na faktu, že se všichni lidé rodí svobodní a rovní a že se nikdo nerodí v okovech. Nebot' i kdyby se všichni rodili svobodní, někteří by se mohli pokusit spoutat druhé okovy, a možná by dokonce byli přesvědčeni, že je správné je spoutat. A naopak, i kdyby se lidé rodili v okovech, mnozí by mohli požadovat jejich odstranění. [...] rozhodnutí nelze z těchto fakt ani z jejich popisu vyvodit" (Popper 2011, 71 - 72).

Decisionistická interpretace ${ }^{2}$ chápe kritický dualismus coby v zásadě totožný $\mathrm{s}$ tzv. Humovou gilotinou (z is nelze vyvozovat ought), což je v dobré shodě s Popperovým tvrzením, že „odpovědnost za naše etická rozhodnutí neseme výhradně my a že

\footnotetext{
${ }^{2}$ Decisionismus bývá spojován s dnes opět populárním Carlem Schmittem. Coby metaetické stanovisko však nemusí vést k přijetí Schmittovy politické filosofie (kterou Victoria Kahnová (2003) trefně diagnostikovala coby př́ípad romantické hysterie). $\mathrm{V}$ podobě, v jaké je prezentováno zde, má naopak mnoho společného se Schmittovým úhlavním neprítelem - pozitivismem kelsenovského typu. Ten se pro změnu výrazně liší od toho, co pozitivismem nazývá Popper, jenž má na mysli částečně pozitivismus vídeňského kruhu a částečně „,pozitivismus“ hegelovský). Srov. Hart 1958.
} 
ji nelze přesunout na nikoho jiného - ani na Boha, ani na přirozenost, ani na společnost, ani na dějiny. [...] At’ přijmeme jakoukoli autoritu, jsme to my, kdo ji přijímá“ (2011, $82-83)$.

Decisionistická interpretace kritického dualismu má dva důležité důsledky, jež ji zásadně odlišují od interpretace objektivistické:

1) Volba cílů (které nejsou pouze prostředky k jiným cílưm) je iracionální. Fakt, že chci jablko, je iracionální; racionalita nastupuje teprve ve chvíli, kdy zvažuji nejlepší způsob, jak ho získat; nebot', jak říká Hume, „rozum sám o sobě nikdy nemůže dát vzniknout ani činu ani chtění, [...] je [v tomto ohledu] otrokem vášní“ a „vášeň, aby mohla být zvána nerozumnou, musí být provázena úsudkem, i tehdy je to však úsudek, nikoli vášeň, co je nerozumné.“3

2) Je možná racionální diskuze o prostředcích, nikoli však o cílech. Mohu se pokusit někomu dokázat, že Sókratés je (is), nebo že není (is not) bezbožník či kazič mládeže. Mohu se také pokusit tomu, kdo by Sókrata rád viděl mrtvého, dokázat, že pokud ho zabije, stihne ho za to trest či odsudek budoucích generací. Pokud však někdo bude přesvědčen, že má (ought to) Sókrata zabít prostě proto, že je to Sókratés, a bude zároveň ochoten nést jakékoli následky svého činu, mohu se maximálně pokusit zapůsobit na jeho emoce (např. vzbudit v něm k Sókratovi soucit), racionálně diskutovat s ním o tom ale nemohu.

Objektivistická interpretace, jak ji představil Shearmur (1996, zvl. 89 - 99; 2009, 342 - 348), vidí v Popperovi ne-naturalistického etického realistu, jehož teorie by, za předpokladu, že by ji plně rozvinul, připomínala Moral Visions Davida McNaughtona. ${ }^{4}$ Co se v Popperových textech zdá být relativismem či subjektivismem, chápe tato interpretace jako pouhé poněkud neobratné vyjádření „obhajoby autonomie etiky“. Klíčovým tvrzením objektivistické interpretace je, že v Popperově vesmíru existují ,absolutní morální standardy“, k nimž je, přinejmenším teoreticky, možné dospět, a to za použití podobných metod, jakými se věda přibližuje k pravdě. Jelikož i zde platí Popperův falibilismus, nemůžeme si být nikdy skutečně jisti, že jsme objektivního standardu dosáhli. To však nemění nic na faktu, že v etice, stejně jako ve vědě, existují objevy a také pokrok, který zde má pouze namísto pravdy coby svou limitu ,správnost“".

\footnotetext{
${ }^{3}$ Hume 2007, 2.3.3. (všechny překlady dosud nepřeložených zdrojů jsou mé vlastní).

${ }^{4}$ Zajímavá je též verze Alexandera Naranieckého (2009), který nachází etický objektivismus v předpokládaném Popperově zkombinování Tarského teorie pravdy s Bühlerovou teorií jazykových funkcí. Srov. však Miller 1999, 68 - 69, a zvl. Stelzer 2009, 277.
} 
Domnívám se, že co se týče Popperova myšlení zhruba od roku 1960, je objektivistická interpretace víceméně správná. ${ }^{5}$ Co se však týče Otevřené společnosti (a dalších textů ze 40. a raných 50. let) považuji za správnější interpretaci decisionistickou.

Popper nikdy nepřiznal, že by v otázce metaetiky změnil názor, a údajně dokonce tvrdil, že problém objektivity norem v Otevřené společnosti „vyřešil“. ${ }^{6}$ Shearmur $(1996,91)$ nicméně již v Political Thought of Karl Popper přiznává, že jeho interpretace ,je v očividném rozporu s částí textu poznámek k Otevřené společnosti“, kde se „Popper zdá kritizovat všechny nabízející se [objektivistické] alternativy [...] včetně Kanta“. V úvodu k After the Open Society již zmiňuje očividný „,posun od mluvení o rozhodnutích $\mathrm{k}$ důrazu na ,návrhy', a nakonec k tomu, co by bylo možné nazvat metodologickým etickým objektivismem Dodatku [z r.] 1961“ (Shearmur 2012, xiv). V článku Critical Rationalism and Ethics pak píše, že „Popperovy názory někdy vyznívají [come over] coby vysoce decisionistické“ a že jakýkoli pokus vystavět objektivistickou etiku na Popperových pozdějších přesvědčeních bude „nekonzistentní $\mathrm{s}$ něčím, co Popper napsal, a to $\mathrm{z}$ důvodu termínů, které při pojednávání těchto záležitostí používal v Otevřené společnosti“" (Shearmur 2009, 342 a 348). To následně opakuje i ve svém př́spěvku ke Cambridge Companion to Popper, kde o Otevřené společnosti mluví dokonce jako o knize „mírně iracionální“ a „téměř existenciálně laděné“" (Shearmur 2016, 358 - 361).

$\mathrm{K}$ tomu je třeba doplnit, že v Otevřené společnosti chybí (v silném kontrastu k dodatku z roku 1961) jakákoli zmínka o „naučitelnosti“ či „nahlédnutelnosti“ „správných“ norem. Naopak, píše se zde (Popper 2011, 72, kurzíva je má), že rozhodnutí nelze vyvodit z faktů právě proto, že „všechna (měnitelná) fakta sociálního života mohou dát podnět k mnoha rưzným rozhodnutím.“ Dále také, že „etické problémy nelze vyřešit racionálními metodami vědy“, a že „totalitarismus není jednoduše amorální. Je to moralita uzavřené společnosti - skupiny, kmene“ (ibid., 115 a 311). V druhém dílu (Popper 2015,357) se pak dokonce explicitně mluví o „primátu iracionálního rozhodování“ a objevuje se zde (223) následující klíčová pasáž:

\footnotetext{
${ }^{5}$ V Popperově Emory Lecture z roku 1956 se sice objevuje cosi jako nárys možnosti rozvíjení konceptu spravedlnosti (Shearmur 2009, 344), ještě v únoru 1959 ale Popper píše dopis Isaihu Berlinovi, v němž vyjadřuje souhlas s některými klíčovými body jeho Dvou pojmů, které jsou (jak uvidíme níže) s objektivismem v poměrně zásadním rozporu. Za pravděpodobný důvod Popperova př́klonu k objektivismu považuji jeho touhu vymezit se proti existencialistům (srov. Popper 2012, 23 - 24; Popper 2015, 386 - 387; Shearmur 2009, 342), prríp. proti sociálnímu konstruktivismu frankfurtské školy.

${ }^{6}$ Mettenheim $(1999,110)$. Shearmur $(2009,345 ; 2012$, xiv) odkazuje v tomto kontextu na pozn. 9 ke 2. kap. Objective Knowledge, kde Popper píše, že v Logik der Forschung „mylně identifikoval hranice vědy s hranicemi diskutovatelnosti“. Podle mého názoru zde však Popper nemá na mysli metaetiku, nýbrž tzv. „metafyzické výzkumné programy““.
} 
Někteří lidé nevidí rádi upalování na hranici, jiní ano. Tento bod [...] je důležitý, nebot' ukazuje, že racionální analýza následků rozhodnutí neučiní toto rozhodnutí racionálním: následky nedeterminují naše rozhodnutí, pokaždé jsme to my, kdo se rozhoduje.

Dalším argumentem pro decisionistickou interpretaci Otevřené společnosti může být fakt, že prakticky jedinými dvěma moderními autory, o nichž se v ní Popper vyjadřuje s nekritickým obdivem, jsou striktní decisionisté Bertrand Russell ${ }^{7}$ a Albert Einstein. ${ }^{8}$ Následující pasáž (Popper 2011, 215) pak považuji za poměrně silnou podporu názoru lorda Boyla (1974, 844 - 845), že kromě tradice russellovské lze Poppera řadit i do tradice humovské:

Věř́m v dualismus faktů na jedné straně a rozhodnutí či požadavků na druhé (neboli dualismus ,je‘ a ,má být'); jinými slovy jsem přesvědčen, že není možné redukovat rozhodnutí či požadavky na fakta, i když s nimi samozřejmě lze nakládat jako s fakty.

S názorem, že metaetika Otevřené společnosti je humeánská, souhlasí i Calvin Hayes (který chce ovšem Poppera v tomto ohledu transgredovat). ${ }^{9}$ Hayes $(2009,72-$ 75) si všímá důležitého faktu, že tato metaetika nutí Poppera uchýlit se v posledních třech kapitolách Otevřené společnosti k „trapně emotivnímu a rétorickému jazyku [...], kterým [u jiných autorů] opovrhuje“. To je, jak jsme si ukázali, jeden z důsledků decisionismu, který ho zásadně odlišuje od objektivismu.

Hayes (ibid.) přirovnává Popperovo chápání rozhodnutí ke Kierkegaardovu skoku viry. Možná by však nemusel zůstat u pouhého přirovnání. Nejenže Popper (2015, 191 - 192, 262, 264, 354, 372 - 373) Kierkegaarda právě ve zmíněných třech kapitolách opakovaně cituje, nýbrž dokonce i Shearmur (1996, 106; 2009, 346; 2016, 352) přejímá Hacohenův (2000) názor, že Popperovo rané myšlení bylo Kierkegaardem značně ovlivněno.

\footnotetext{
${ }^{7}$ Russell $(2010,504):, \ldots$ the war may have sprung from lies told by one party which may seem an admirable foundation to the contest until it appears that there was equal mendacity on the other side. To arguments of this sort there is no purely rational conclusion. [...] For such reasons, I had come to agree with Santayana that there is no such thing as ethical knowledge."Srov. též Boyle 1974, 844. ${ }^{8}$ Einstein (2019): „I know that it is a hopeless undertaking to debate about fundamental value judgments. For instance if someone approves, as a goal, the extirpation of the human race from the earth, one cannot refute such a viewpoint on rational grounds".

${ }^{9}$ Hayes většinou mluví o „weberiánské“ tradici (do které řadí i Huma). Toto označení nepovažuji za zcela št’astné, nebot', jak Hayes $(2009,142)$ sám upozorňuje, Weber nerozlišoval mezi dichotomiemi is-ought a fakt-hodnota. Jeho demarkace diskutovatelnosti byla proto striktnější, než zde hájený (humovský) decisionismus považuje za nutné.
} 
To by částečně vysvětlovalo i některé poněkud neortodoxní názory, které Popper zastával ve svých novozélandských přednáškách. Jelikož tyto přednášky vznikaly paralelně s Otevřenou společností, považuji je za důležitý pramen k její interpretaci. V kontextu metaetiky nás bude zajímat především „Science and Religion“, ve které Popper (2012, 41 - 48) tvrdí, že mezi vědou a náboženstvím neexistuje „žádný skutečný střet [clash]“, náboženstvím zde nicméně rozumí vše, co poskytuje odpovědi na otázky ,jak bychom měli jednat [ought to act], o co bychom měli [ought to] v životě usilovat - pro sebe sama i pro lidstvo jako celek“. Do takto chápané kategorie mu kromě náboženství v běžném slova smyslu spadají nejen nejrůznější sekulární etické nauky, ale také „vědecká oddanost pravdě“, a dokonce i „různé formy totalitarismu a rasismu“. V opozici $\mathrm{k}$ tomu: „....v̌̌echny vědecké otázky mohou být vyjádřeny ve formě jak se ta a ta věc chová za různých okolností? Všechny vědecké odpovědi mají formu deskriptivních tvrzení.“"

Rád bych tento oddíl zakončil Shearmurovým $(2009,343)$ vlastním upozorněním na jeden velice zásadní problém objektivismu vůbec (spíše než objektivistické interpretace Otevřené společnosti). Pokud souhlasíme s Popperovým názorem z Logiky vědeckého bádání, že subjektivní pocit jistoty nemůže být kritériem dosažení pravdy, proč bychom si měli myslet, že stejně subjektivní svědomí vypovídá něco o objektivní morální správnosti? Jak říkal již Arnold Brecht (2015, 485), „Vědecká Metoda nemůže popírat, a nepopírá, že by mohly existovat absolutní normy spravedlnosti; trvá pouze na tom, že nemohou být vědecky ověřeny. “ Přinejmenším pro kognitivně poctivého člověka tedy (poněkud paradoxně vyjádřeno) není decisionismus volbou, nýbrž nutností.

\section{Relativismus, racionální kritika a otev̌rená společnost}

Shearmurovým hlavním důvodem pro odmítnutí decisionistické interpretace je Popperovo opakované ujištování, že jeho kritický dualismus nevede k relativismu. (Shearmur 1996, 91; Shearmur 2009, 342) V tomto oddíle (1) ukáži, proč a v jakém rozsahu implikace decisionismus $\rightarrow$ relativismus neplatí. Popper si toho mohl být vědom, a přesto zatoužit po větší etické jistotě (ergo jeho pozdější př́iklon k objektivismu). Ukáži (2), že tato větší jistota je ve skutečnosti špatně slučitelná s jeho vlastním ideálem otevřené společnosti.

Důležitým autorem zde pro nás bude Christoph von Mettenheim, který založil svou právní teorii na Popperově dualismu z Otevřené společnosti, později si však od něj vysloužil osočení z relativismu, když označil za nebezpečný názor, že „koncept ,správnosti` ve vztahu k normám může být použit přesně ve stejném smyslu, jako koncept ,pravdy“ ve vztahu k faktům a popisům“. (Mettenheim 1999, 119) Metten- 
heim ve své odpovědi (na níž již Popper nestihl zareagovat) dokazuje, že jeho (decisionistická) teorie připouští objektivní racionální kritiku přinejmenším ve dvou ohledech: můžeme poukázat na vnitřní nekonzistentnost nějakého morálního či právního systému a můžeme poukázat na nechtěné nezamýšlené důsledky nějakého návrhu (ibid., $118-119$ ).

Jak ukázal již Albert Hirschman (1991), tyto dva způsoby kritiky jsou částečně vzájemně propojeny a lze je dále rozdělit na argumenty perverzností (proč navrhované prostředky oddalují slibovaný cíl, místo aby ho přibližovaly), zbytečností (proč navrhované prostředky nedosáhnou slibovaného cíle) a ohrožením (proč navrhované prostředky ohrozí nějaký jiný přijímaný cíl). ${ }^{10}$ Zhruba takovýto typ argumentů měl podle mého názoru na mysli Popper, když s odkazem na L. J. Russella mluvil v Otevřené společnosti o diskutovatelnosti návrhů (Popper 2011, 242 - 243; Boyle 1974, 852).

Sám Popper $(2011,72)$ také uvádí třetí aspekt, v němž decisionismus nemusí být relativistický:

Je nepochybné, že naše rozhodnutí musí být v souladu s prrírodními zákony (včetně zákonů lidské fyziologie a psychologie), mají-li vůbec být kdy uskutečněna: jsou-li s nimi v rozporu, nelze je prostě uskutečnit.

Jedná se o verzi známého kantovského ought implies can. ${ }^{11}$ Hayes $(2009,168$ 169) na kombinaci tohoto principu s modus tollens zakládá svůj pokus o objektivistickou transgresi Humovy gilotiny:

1) Můžeme platně vyvodit is z ought (nikoli naopak).

2) Můžeme, z principu, vyvrátit is tvrzení. Tedy:

3) můžeme vyvrátit ought (pomocí modus tollens), aniž

4) ought samo musí být pravdivé či nepravdivé, a tedy

5) racionální volba je možná.

${ }^{10} \mathrm{~K}$ aplikaci těchto kategorií na ústavní právo viz Vermeule (2012).

${ }^{11}$ Abych zamezil př́íp. nedorozuměním: Tento princip interpretuji ve stylu Shapiro 2018, 6 - 9. 
Tato úvaha coby základ objektivismu nedostačuje (a to ani pokud přimhouříme oko nad očividným modálním problémem prvního kroku). ${ }^{12}$ Stejně jako obě výše uvedené formy racionální kritiky totiž předpokládá racionalitu. Všichni lidé ale nemusejí být plně racionální. A nemusí se jednat jen o blázny či tvrdohlavé zabedněnce, nýbrž např. i o vyznavače sartrovské „radikální svobody“ či o lidi, kteří v paradoxech některých teorií vidí svatá mysteria, na jejichž rozluštění omezený lidský rozum jednoduše nedostačuje. Člověku, který je dobrovolně a vědomě nekonzistentní či který se vědomě snaží o nemožné, se můžeme pokusit ukázat, že jeho iracionalita je v rozporu s nějakou (jinou) hodnotou, kterou vyznává (že v případě většiny cílů je perverzní, zbytečná a/či ohrožujicí). Nechceme-li však být represivní, není $\mathrm{v}$ našich silách udělat více pro to, abychom ho přiměli respektovat $i s$-pravidlo, že ought implies can (srov. Cehelník 2009).

Poslední aspekt, $v$ němž by bylo možné říci, že decisionismus nemusí být relativistický, formuloval Isaiah Berlin. Třebaže (z podstaty subjektivní) cíle není možné objektivně predepisovat, lze je zkoumat v popisné rovině. A z tohoto zkoumání vyplývá, že lidé sdílejí jisté základní potřeby (napr. potřebu svobody, rovnosti, loajality...). Ostatně, kdyby je nesdíleli, nebyli by vůbec schopni si navzájem porozumět (navzájem se do sebe vcítit). V čem se od sebe lidé liší, jsou především vzájemné poměry těchto základních potřeb. ${ }^{13}$

$\mathrm{S}$ tím, stejně jako s uvedenými možnostmi racionální kritiky, souvisí problematika etických „objevư“. V dodatku z r. 1961 Popper $(2015,396)$ píše, že „pokrok“ v oblasti „poznání“ norem je způsoben např. objevem, že jednání $x$ způsobuje utrpení. Považuje takový objev za normativní v tom smyslu, že nás přiměje od jednání $x$ upustit. To však může být pravda pouze za předpokladu, že zastáváme maximu, ze které vyplývá, že při dosahování cíle $Y$ je neprrijatelné působit utrpení (přičemž $Y$ je cílem, k jehož dosažení jsme užívali jednání $x$ ). Objev, že jednání $x$ způsobuje utrpení, tedy sám o sobě normativní není. ${ }^{14}$ Normativní důsledky má pouze ve spojení s maximou

\footnotetext{
12 (Druhý) Hayesův pokus o toto založení spočívající v postulování default principles etického poznávání považuji za vyvrácený argumentem z posledního odstavce minulého oddílu, a kromě toho neslučitelný s Popperovým $(1991,134)$ názorem, že „neexistují autoritativní zdroje poznáni““.

${ }^{13}$ Přehledné shrnutí se nachází v třetí části Berlinova dopisu Roccu Pezzimentimu z 30. listopadu 1992 (Pezzimenti 2011, 272 - 276 a 282 - 284), viz ale také např. Berlin 2013, 313 - 318.

${ }^{14}$ Termín normativní použivám ve významu vnitřně přijaté maximy „Čiň/Nečiň X!“”. Tento význam podle mého názoru odpovídá Popperově polemice s naturalistickým Rousseauovým protestem proti otroctví citované na začátku prvního oddílu. Děkuji anonymnímu recenzentovi za cenné doporučení přidat tuto definici.
} 
působení utrpení za daných okolností zakazující. Pro názornost převed'me do sylogismů: ${ }^{15}$

Platný úsudek:

Neplatný úsudek:

$\mathrm{P}_{1}$ : Jednání $x$ způsobuje utrpení.

$\mathrm{P}_{1}$ : Jednání $x$ způsobuje utrpení.

$\mathrm{P}_{2}$ : Nepůsobit utrpení ve snaze dosíci cíle $Y$ !

Z: Nepoužívat jednání $x$ !

$Z$ : Nepoužívat jednání $x$ ve snaze dosíci cíle $Y$ !

Platný (nikoli nutně pádný) je samozřejmě také následující, pacifistický, úsudek:

P1: Jednání $x$ způsobuje utrpení.

P2: Nepůsobit utrpení!

Z: Nepoužívat jednání $x$ !

Popper pacifistou nebyl. ${ }^{16}$ I kdyby však byl, nic by to, jak vidno, neměnilo na faktu, že bez normativní premisy není možné získat normativní závěr.

Někdo by snad mohl označit za etický „objev“ také přehodnocení inklinací systému $u_{1}$ na základě zapojení systému2. (Stanovich a West 2000; Evans a Stanovich 2013) Typickým př́kladem takovéhoto „objevu“ by byla následující situace:

Pan Novák zahlédne na ulici dva líbající se muže. Jeho první reakce (systém $)_{1}$ je zhnusení a touha takové jednání zakázat. Následně si vzpomene, že je liberálem a že za jednu z obecně nejdůležitějších maxim považuje každý at'si dělá co chce, pokud tím nikomu neubližuje. Na základě tohoto rozpomenutí dojde k závěru (,objeví“), že líbání dvou mužů zakazovat nechce.

Z Hayesovy $(2009,165$ - 166) interpretace by se mohlo zdát, že právě tento typ „objevư“ (o mnoho komplikovanějších, principiálně však stejných) měl Popper na mysli, když hovořil o „objektivní normativitě“ coby důsledku nezávislé existence norem ve světěs. Z logického hlediska je však situace stejná jako ve výše pojednaném př́ípadě „objevu“ utrpení. Co pan Novák „objevil“, je, že liberální etická teorie, kterou již zastával, mu zakazuje, aby zakazoval druhým dvěma pánům vzájemné líbání. Také jeho úvahu můžeme převést do sylogismu:

${ }^{15}$ K používání sylogismů za účelem ilustrace Humovy gilotiny mne inspiroval Hare 1991. Pro decisionistickou interpretaci Hara viz např. Hayes 2009, 139 a 150 - 151; pro podobnosti jeho a Popperovy teorie viz ibid., 71.

16 Otevřenou společnost dokonce několikrát označil za svůj ,„př́spěvek k válečnému úsilí“ - Popper 1995, 109 - 115; Popper 2012, 87, 133 a 216; Popper 2015, 399. 
$\mathrm{P}_{1}$ : Nezakazovat, co nikomu (a zvláště nikomu mimo toho, kdo to dělá) neubližuje!

$\mathrm{P}_{2}$ : Líbání s osobou stejného pohlaví nikomu neubližuje.

Z: Nezakazovat líbání s osobou stejného pohlaví!

Tento úsudek uzná za platný i člověk, který ho nebude považovat za pádný - tj. který nebude sdílet páně Novákův liberalismus a nebude souhlasit s deskriptivní premisou $\mathrm{P}_{2}$. Kdyby se takovým člověkem v budoucnu stal pan Novák sám (např. na základě konverze $\mathrm{k}$ některému ze striktnějších křest’anských učení), učinil by (ze své perspektivy) „objev“ podobný výše pojednanému „objevu“ utrpení: zjistil by (resp. domníval by se, že zjistil), že co doposud považoval za nikomu neubližující, ve skutečnosti ubližuje.

Tato možnost v budoucnosti pana Nováka je velmi důležitá, nebot' ukazuje, že čistě na základě deskriptivní premisy a bez změny premisy normativní je možné dojít $\mathrm{k}$ opačným normativním závěrům. Jasně tak vidíme, že překlenutí propasti mezi is a ought (i kdyby se někdy někomu podařilo) nemusí být tak velkou pomocí v boji s relativismem, jak se zdá. Novák ${ }_{1}$ a Novák 2 se co do maxim neliší (Novák 2 stále věří, že není důvod zakazovat, co nikomu neubližuje). V čem se liší je čistě deskriptivní teorie o povaze světa: Novák 2 se (na rozdíl od Nováka $)_{1}$ domnívá, že za homosexuální jednání príijde trest v posmrtném životě a že ( $\mathrm{v}$ tomto bodě se již $\mathrm{s}$ Novákem 1 mohou shodovat) čím veřejnější takové jednání bude, tím více lidí mu „propadne“ (v důsledku čehož jim bude ublíženo).

Na základě výše uvedené Berlinovy teze bychom snad dokonce mohli říci, že rozdílné deskriptivní teorie, zvláště co se týče posmrtného života a dalších typů metafyzických trestů (karma apod.), jsou příčinou horších konfliktů než rozdílné základní maximy, nebot' co se maxim týče, jedná se spíše o negotiable konflikty typu more-or-less než o non-negotiable konflikty typu either-or (Hirschman 1994).

Popperova snaha vyhnout se relativismu (a obvinění z něj) působí často až úzkostně. Především z jeho osobních dopisů se zdá, že hlavní motivací bylo v tomto príípadě jeho přesvědčení, že „relativismus vede k Nietzschemu a Hitlerovi““ (Mettenheim 1999, 119).

Nakolik se zde mluví o relativizaci korespondenční teorie pravdy, vědecké metody atd. na rovině $i s$, zdá se tato obava oprávněná. Přesvědčení, že „pravd“ je více, že jedna je stejně dobrá jako kterákoli jiná atd. zajisté velice usnadňuje šíření konspiračních teorií a ignoraci rozumné kritiky (Russell 1941, 77nn.; Popper 2002; Popper 2011, 150 a 289). Fašismus a nacismus (a částečně také leninismus - nakolik vychází 
ze Sorela) navíc ideu pravdy ve vědeckém smyslu coby součást své ideologie nepotřebují. Věří totiž v „pravdu“ citu: „mýtu krve a půdy“ atd. ${ }^{17}$

Právě proto je však situace odlišná, co se týče relativismu etického. Domnívat se, že přispěl ke zborcení viktoriánské morálky, oslabení moci církve atd., je samozřejmě zcela rozumné. Velice podobný efekt by však měla i Popperova verze objektivismu, nauka Kantova či Patočkova - každá etika, která důsledně respektuje autonomii jednotlivce (at' je jinak jakkoli objektivistická). Nacismus, stejně jako jakákoli jiná utiskujicí ideologie, potřebuje ideu etické jistoty, nebot' právě na ni se odvolává, když autonomii jedinců porušuje. Popper sám v tomto ohledu zcela správně nachází (pra)kořeny nacismu v Kritiově biologickém naturalismu a Hegelově etickém poziti$v i s m u$, které (z odlišných pozic) docházejí ke stejnému závěru: $\mathrm{k}$ právu silnějšího (might makes right). Relativismus ze své podstaty nejenže nemůže poskytnout ideu jistoty, nýbrž nemůže poskytnout vůbec žádnou jednotící ideologii: jeho síla, má-li vůbec nějakou, je vždy pouze destruktivní. ${ }^{18}$

Berlin (1999, 237 - 239) poznamenává, že je to právě vyhlášení autonomie jednotlivce, jímž se Kant na poslední chvíli zachrání před totalitárními důsledky svého (objektivistického) pojetí svobody. To samé, domnívám se, platí i pro Patočku. Popperovi slouží ke cti, že ani v etice nezapomíná na svůj falibilismus: jelikož si nikdy nemůžeme být jisti, že jsme skutečně dosáhli „,pravého dobra“ (etického ekvivalentu pravdy), nesmíme potírat svobodnou diskuzi o morálních otázkách. Takto podložena je jeho verze autonomie jednotlivce mocnější hrází proti implicitnímu totalitarismu než autonomie Kantova či Patočkova (jejichž podložení je možná podobného rázu, rozhodně ale méně explicitní). To však nic nemění na faktu, že v objektivistické etice všech tří filosofů zárodek totalitní ideologie je: hluboko ukrytý a spoutaný primátem autonomie, ale je. Spočívá v přesvědčení, že ,někde tam venku“ (nebo uvnitř) existuje jediné správné ř rěení všech společenských problémů - jen ho najít.

\footnotetext{
${ }^{17}$ To samé samozřejmě nemusí platit, co se týče praktického fungování. Zde musí vědu a vnější realitu do určité míry respektovat každý, kdo chce přežít. B. Russell $(1967,132)$ vypráví v tomto ohledu poučný př́běh, jak se Kanad'ané a Rusové snažili vyšlechtit mrazuodolnou pšenici: první postupovali podle tehdy nejnovějších genetických teorií, druzí podle zásad dialektického materialismu.

${ }_{18}$ Jeden z anonymních recenzentů mi doporučil odkázat na tomto místě na tezi Josepha Ratzingera o „diktatuře relativismu“. Odkáži však raději na Tuck 1979 a Hill 1984, kteří (zvláště v kombinaci) podle mého názoru přesvědčivě ukazují, že doba ovládaná vírou v prirozený zákon byla přinejmenším stejně relativistická jako dnešek (at' už se jednalo o spor o chudobě mezi dominikány a františkány, nebo o strany v anglické občanské válce sahající od absolutistických „kavalírü“ přes puritánské puritány po komunistické levellery, anarchistické diggery a programově promiskuitní rantery všechny tyto skupiny považovaly samy sebe za pravé křest’any a argumentovaly přirozeným zákonem). Tato poznámka není výrazem neúcty k náboženství; pouze úcty $\mathrm{k}$ faktům (prokazované mj. tím, že cituji právě Tucka a Hilla, s jejichž politickými názory nesouhlasím, ale které považuji za vynikající historiky).
} 
Co když ale jediné správné řešení neexistuje? Co když je „formální kontradikcí, metafyzickou chimérou“ vedoucí pouze „k apriorním prokrustovským barbarstvím, k vivisekci reálných lidských společností“, jak tvrdí Berlin (1999, 274 a 277 - 278)? Za jednu z hlavních výhod decisionistické interpretace kritického dualismu považuji, že je s touto plausibilní možností slučitelná, a za hlavní nevýhodu objektivistické interpretace, že není (jak dokazuje s Berlinem souhlasící von Mettenheim 1999, 123).

Jak jsme viděli, decisionismus nemusí vést k relativismu. Dokonce i relativismus se však zdá být lépe slučitelný s demokracií než objektivismus. Protože jestliže jsem přesvědčen, že existuje jediné správné řešení, proč bych měl cítit jakýkoli respekt k názoru většiny? (srov. Berlin 2000; Mettenheim 1999, 123)

Hayes $(2009,144)$, který sdílí Popperovu potřebu objektivní etiky, považuje za intelektuálně největšího představitele opačné (decisionistické) pozice Arnolda Brechta. Je zajímavou ironií, že Brecht byl jedním z mála představitelů výmarské státní správy, kteři se otevřeně postavili proti Hitlerově převzetí moci (byl za to vězněn, propuštěn na základě intervence ne-nacistických ministrů, emigroval do Spojených států a po válce se podílel na tvorbě ústavy SRN).

Tento Brecht $(2015,156$ - 157) chápal pluralitní parlamentní demokracii jako „logický důsledek faktu, že věda nemá schopnost rozhodnout, který ze škály [politických] názorů je správný.“ Další z představitelů decisionistické pozice (a také další veterán praktické politiky), lord Boyle $(1974,851)$, se ve svém článku pro změnu hlásí k následující zásadě ,jednoho svého prítele“: „Unless one recognises there are some principles whose violation makes life not worth living, life isn't worth living." V o něco méně patetické tónině pak upozorňuje (ibid., 845 a 850), že Humova gilotina je skvělým podkladem „,práva jednotlivců kritizovat své vládce a institucionální rámec svých společností“ a že autoritáři se především bojí lidí, kteří nejenže jsou ochotní přijmout zodpovědnost za vlastní rozhodnutí (včetně rozhodnutí podřídit se autoritě), ale ještě tuto zodpovědnost požadují coby právo.

\section{Závěr}

V prvním oddílu jsem předložil důvody svého přesvědčení, že Otevřené společnosti odpovídá lépe decisionistická než objektivistická interpretace kritického dualismu. Upozornil jsem, že (v kontrastu k pozdějším dodatkům) chybí v celém původním textu jakákoli zmínka o „naučitelnosti“ či „nahlédnutelnosti“ „správných“ norem, a naopak se zde vyskytují explicitní přihlášení k humovskému dualismu is a ought, důraz na odpovědnost za vlastní rozhodování, pasáže naznačující či explicitně postulující „primát iracionálního rozhodování“ a obdiv ke striktním decisionistům Bertrandu Russellovi a Albertu Einsteinovi. Poukázal jsem také na Popperovo obecně 
přijímané rané ovlivnění Kierkegaardem a v neposlední řadě na další jeho texty, které všechny svědčí pro mou tezi, že až do druhé poloviny 50 . let byl decisionistou.

Ve druhém oddílu jsem nejprve ukázal, proč a v jakém rozsahu neplatí, že decisionismus vede $k$ relativismu. Argumentoval jsem, že objektivní racionální kritika je v rámci decisionismu nejen možná, nýbrž také žádoucí, a to jednak co se týče upozorňování na vnitřní nekonzistentnost nějakého morálního či právního systému, jednak ve formě poukazování na nechtěné nezamýšlené důsledky. Odkázal jsem v této souvislosti na slavnou Hirschmanovu triádu argumentů perverzností, zbytečností a ohrožením jiného přijímaného cíle, které decisionismus všechny umožňuje (a rád používá), stejně jako kantovský princip ought implies can. Decisionismus nevede k relativismu také $\mathrm{v}$ tom ohledu, že uznává možnost zkoumat cíle v popisné rovině (a skrze toto zkoumání zpravidla dochází k závěru, že lidé se od sebe liší spiše poměry svých základních potřeb, než že by měli potřeby diametrálně odlišné). Objektivismus naopak není tak velkou pomocí v boji s relativismem, jakou se zdá, nebot' lidé často dospívají k opačným požadavkům jednání čistě na základě deskriptivních premis, které jsou navíc častěji než ty normativní non-negotiable. Skrze logický rozbor normativních a deskriptivních soudů jsem se dostal k druhému bodu, totiž ke svému tvrzení, že objektivismus je v důsledku neslučitelnýs ideálem, otevrené společnosti ‘. Dokazoval jsem, že zatímco utiskující ideologie potřebují koncept etické jistoty (na nějž by se mohly odvolávat při porušování autonomie jednotlivců), relativismus žádnou jednotící ideologii poskytnout nemůže. Objektivismus nutně předpokládá existenci jediného správného řešení, a proto v sobě nese zárodky totalitarismu. Decisionismus je naopak skvělým podkladem klíčového demokratického práva kritizovat ty, kdo vládnou. (K tomu, že toto právo je skutečné sine qua non demokracie viz kromě Poppera i např. Peroutka 1991.)

Rád bych tento článek zakončil obecnější úvahou nad smysluplností publikování objektivistických textů. Zdá se, že lidé často hájí objektivismus z utilitaristických důvodů. Domnívají se, že postulování objektivity hodnot učiní jejich bližní morálnějšími. Např. Sandra Pralongová (1999) očividně věří, že její euangelion doplnění ideálu otevřené společnosti o konkrétní etickou nauku vyvede postkomunistické země $\mathrm{z}$ „divoké kapitalistické džungle“ ovládané sobectvím.

Kdyby bylo možné racionálně se rozhodnout přijmout za svou morální hodnotu, a kdybychom žili ve společnosti, kde většina činí taková rozhodnutí na základě četby akademických textů, možná by tomu tak mohlo být.

Snad se najdou tací, kteří budou tvrdit, že první z těchto podmínek platí. Doufám však, že nikdo z mých kolegů není natolik narcistický, aby se domníval, že platí ta druhá. Nemáme status proroků. Naše texty nepůsobí na masy. A kdyby snad někdo věril, že morálka, již vlil do zlomečku populace, který četl jeho texty, se coby jakýsi 
virus lásky bude širrit geometrickou řadou, rád bych ho odkázal na texty Iana Shapira (např. 2018, 162 - 166), který přesvědčivě ukazuje, jak naivní víra v podobný domino efekt většinou bývá.

Akademické texty sice nečtou masy, čte je ale přinejmenším část elity. A ta má vliv na podobu zákonů a jejich aplikaci. Většina lidí pro sebe nehledá výhody na úkor ostatních z přesvědčení, pouze nechce být za hlupáky. ${ }^{19}$ Jedním z důvodů, proč nefunguje moralistický domino efekt, je, že vyžaduje světce - světce, nebo donquijoty: vyžaduje lidi ochotné být za hlupáky. Neříkám, že takoví lidé neexistují, pouze, že jich nikdy nebude dostatek. If men were angels, no government would be necessary. ${ }^{20}$ Co potřebujeme, je systém, v němž se morální člověk nemusí cítit jako hlupák. Za posledních třicet let jsme $\mathrm{v}$ tomto ohledu ušli v našem koutě Evropy velký kus cesty. Nepopírám, že na tom má svou zásluhu i morálka: „Instituce jsou jako pevnosti: musí být dobře navrženy $a$ mít dobrou posádku.“"21 Svět ale musí být učiněn pro morálku bezpečným, jinak se do něj morálka neodváží. Vztah je to svým způsobem dialektický: Zkoušíme být morální. Když se nespálíme, pokračujeme. Pokud je cena př́lišs vysoká, málokdo je ochoten ji zaplatit. A je úkolem systému, aby nebyla vysoká za život poctivý, nýbrž za život nepoctivý. Pokud je má generace morálnějšś než generace Prognostického ústavu, je to proto, že nám $\mathrm{k}$ tomu generace našich rodičů připravila podmínky. Naším úkolem se nyní zdá být rozšírit tyto podmínky jak do spodních, tak do nejvyšších pater společnosti - tj. zařídit, aby pro všechny platilo, že poctivost se vyplácí: aby „vládlo právo, a ne lidé“, kteří mohou ostatní šikanovat a vykořistovat. ${ }^{22}$ Snad se mi podařilo dokázat, že morální objektivismus k tomu nepotřebujeme.

\section{Literatura}

BERLIN, I. (1999): Čtyři eseje o svobodě. Praha: Prostor.

BERLIN, I. (2000): Democracy, Communism and the Individual. The Isaiah Berlin Virtual Library. [online]. Dostupné na: http://berlin.wolf.ox.ac.uk/lists/nachlass/demcomind.pdf (Navštívené: 27. 1. 2020).

BERLIN, I. (2013): The Crooked Timber of Humanity. Princeton - Oxford: Princeton University Press.

BOYLE, (1974): Karl Popper's Open Society. In: Schilpp, P. A. (ed.): The Philosophy of Karl Popper. La Salle: Open Court, $843-858$.

BRECHT, A. (2015): Political Theory. Princeton: Princeton University Press.

BURÁŇ (2019): Popperův ahistorismus: případ peloponnéské války. Pro-Fil, 20 (1), 2 - 15. DOI: https://doi.org/10.5817/pf19-1-1860.

\footnotetext{
${ }^{19}$ Hobbes (2009, zvl. kap. XIII).

${ }^{20}$ Madison $(2009,264)$.

${ }^{21}$ Popper $(2011,133)$.

${ }^{22}$ Harrington (1992, 8); pro praktický návod viz např. Pettit (2014) či Shapiro (2018), ale také Popper $(2011$, zvl. 127 - 134). Apart from Philip Pettit, I would like to thank my grandfather for discussing this topic with me and sharing his practical life-long experience.
} 
CEHELNÍK, M. (2009): Kritický racionalizmus ako morálne rozhodnutie. Filozofia, 64 (6), 545 - 551.

EINSTEIN, A. (2019): On Freedom. In: Einstein, A., Planck, M., Heisenberg, W.: Colleagues in Genius: Out of My Later Years, Scientific Autobiography, and Nuclear Physics. New York: Open Road Media.

EVANS, J. St. B. T., STANOVICH, K. E. (2013): Dual-Process Theories of Higher Cognition: Advancing the Debate. Perspectives on Psychological Science, 8 (3), 223 - 241. DOI: https://doi.org/10.1177/1745691612460685

HACOHEN, M. (2000): Karl Popper: The Formative Years. Cambridge - New York: Cambridge University Press.

HARE, R. M. (1991): The Language of Morals. Oxford: Oxford University Press.

HARRINGTON, J. (1992): The Commonwealth of Oceana and A System of Politics. Cambridge: Cambridge University Press.

HART, H. L. A. (1958): Positivism and the Separation of Law and Morality. Harvard Law Review, 71 (4), 593 - 629. DOI: https://doi.org/10.2307/1338225

HAYES, C. (2009): Popper, Hayek and the Open Society. London - New York: Routledge.

HIRSCHMAN, A. O. (1991): The Rhetoric of Reaction: Perversity, Futility, and Jeopardy. Cambridge, MA: Belknap Press.

HIRSCHMAN, A. O. (1994): Social Conflicts as Pillars of Democratic Market Society. Political Theory, 22 (2), 203 - 218. DOI: https://doi.org/10.1177/0090591794022002001

HILL, C. (1984): The World Turned Upside Down: Radical Ideas During the English Revolution. Penguin Books.

HOBBES, T. (2009): Leviathan. Praha: Oikúmené.

HUME, D. (2007): A Treatise of Human Nature. Vol. 1. Oxford - New York: Oxford University Press.

KAHN, V. (2003): Hamlet or Hecuba: Carl Schmitt's Decision. Representations, 83 (1), 67 - 96. DOI: https://doi.org/10.1525/rep.2003.83.1.67

KEUTH, H. (2005): The Philosophy of Karl Popper. Cambridge - New York: Cambridge University Press.

MADISON, J. (2009): Federalist No. 51. In: The Federalist Papers. New Haven: Yale University Press.

METTENHEIM, C. von (1999): The Problem of Objectivity in Law and Ethics. In: Jarvie, I. - Pralong, S. (eds.): Popper's Open Society After Fifty Years. London - New York: Routledge, 110 $-126$.

MILLER, D. (1999): Popper and Tarski. In: Jarvie, I. - Pralong, S. (eds.): Popper's Open Society After Fifty Years. London - New York: Routledge, 57 - 71.

NARANIECKI, A. J. (2009): Logic and The Open Society: Revising the Place of Tarski's Theory of Truth Within Popper's Political Philosophy. In: Parusníková, Z. - Cohen, R. S. (eds.): Rethinking Popper. Dordrecht: Springer, $257-271$.

O'HEAR, A. (1980): Karl Popper. London: Routledge \& Kegan Paul.

PEROUTKA, F. (1991): Doslov. In: Peroutka, F: O věcech obecných, sv. II. Praha: Státní pedagogické nakladatelství, $591-593$.

BOYLE, (1974): Karl Popper's Open Society. In: Schilpp, P. A. (ed.): The Philosophy of Karl Popper. La Salle: Open Court, $843-858$.

PETTIT, P. (2014): Just Freedom. New York - London: Norton \& Company.

PEZZIMENTI, R. (2011): The Open Society and Its Friends: with letters from Isaiah Berlin and Karl R. Popper. Leominster: Gracewing.

POPPER, K. R. (1991): Objective Knowledge. Oxford: Clarendon Press.

POPPER, K. R. (1995): Věčné hledání. Praha: Prostor.

POPPER, K. R. (2002): On the Sources of Knowledge and Ignorance. In: Popper, K. R.: Conjectures and Refutations. London - New York: Routledge.

POPPER, K. R. (2011): Otevřená společnost a jeji neprátelé. Vol. I. Praha: Oikúmené. 
POPPER, K. R. (2012): After The Open Society. London - New York: Routledge.

POPPER, K. R. (2015): Otevrená společnost a její nepřátelé. Vol. II. Praha: Oikúmené.

PRALONGOVÁ, S. (1999): Minima Moralia: is there an ethics of the open society? In: Jarvie, I. Pralong, S. (eds.): Popper's Open Society After Fifty Years. London - New York: Routledge, $127-143$.

RUSSELL, B. (1941): Let the People Think. London: Watts \& Company.

RUSSELL, B. (1967): Philosophy and Politics. In: Bambrough, R. (ed.): Plato, Popper, and Politics. Cambridge: Heffer \& Sons.

RUSSELL, B. (2010): Autobiography. London - New York: Routledge.

SHAPIRO, I. (2018): Politics against Domination. Cambridge, MA - London: Harvard University Press.

SHEARMUR, J. (1996): The Political Thought of Karl Popper. London - New York: Routledge.

SHEARMUR, J. (2009): Critical Rationalism and Ethics. In: Parusníková, Z. - Cohen, R. S. (eds.): Rethinking Popper. Dordrecht: Springer, 339 - 356.

SHEARMUR, J. (2012): Editorial Introduction. In: Popper, K. R.: After The Open Society. London - New York: Routledge, viii - xxx.

SHEARMUR, J. (2016): Popper's Politics and Political Thought. In: Shearmur, J. - Stokes, J. (eds.): The Cambridge Companion to Popper. New York: Cambridge University Press, 352 - 376.

STANOVICH, K. E., WEST, R. F. (2000): Individual differences in reasoning: Implications for the rationality debate? Behavioral and Brain Science, 23, 645 - 726. DOI: https://doi.org/ 10.1017/S0140525X00003435

STELZER, H. (2009): Popper and Communitarianism: Justification and Criticism of Moral Standards. In: Parusníková, Z. - Cohen, R. S. (eds.): Rethinking Popper. Dordrecht: Springer, 273 $-285$.

TUCK, R. (1979): Natural Rights Theories: Their Origin and Development. Cambridge University Press.

VERMEULE, A. (2012): Precautionary Principles in Constitutional Law. Journal of Legal Analysis, 4 (1), 181 - 222. DOI: https://doi.org/10.1093/jla/las003.

Př́íspěvek vznikl za podpory MŠMT, grant IGA_FF_2019_018

Jan Buráň

Katedra filozofie

Filozofická fakulta

Univerzita Palackého v Olomouci

Křržžkovského 12

77180 Olomouc

Česká republika

e-mail: jan.buran01@upol.cz

ORCID ID: https://orcid.org/0000-0002-9386-5534 